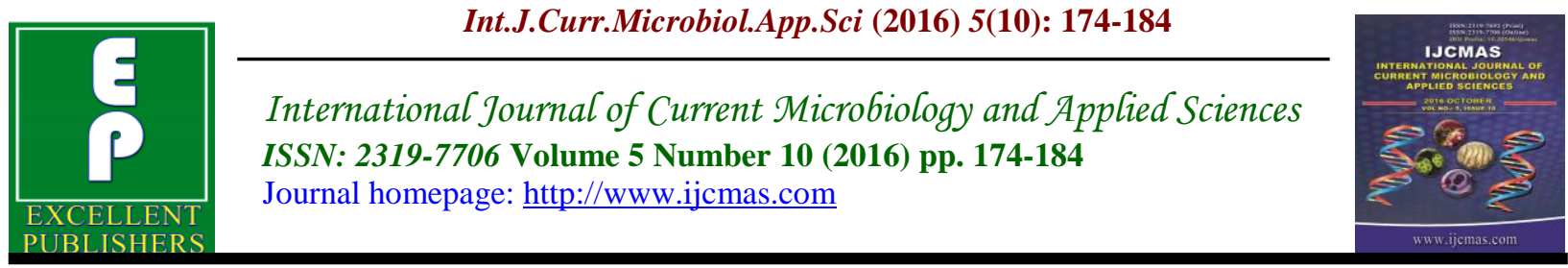

Original Research Article

http://dx.doi.org/10.20546/ijcmas.2016.510.020

\title{
Alkaline Protease Production by Aspergillus terreus BAB-346 using Poultry Litter Waste
}

\author{
Gopalkumar G. Raol ${ }^{1 *}$, Priyanka M. Patel $^{1}$, B.V. Raol ${ }^{2}$ and Rakeshkumar R. Panchal ${ }^{3}$ \\ ${ }^{1}$ Department of Microbiology, Shri A.N. Patel P.G. Institute, Sardar Patel University, \\ Anand, Gujarat, India \\ ${ }^{2}$ Department of Microbiology, Shri P. H. G. Muni, Arts and Science College, \\ Gujarat University, Kalol, Gujarat, India \\ ${ }^{3}$ Department of Microbiology, M.B. Patel Science College, Sardar Patel University, \\ VallabhVidyanagar, Gujarat, India \\ *Corresponding author
}

Keywords

Alkaline Protease, Aspergillus terreus,

Poultry litter, Agro-industrial wastes.

\section{Article Info}

Accepted:

12 September 2016

Available Online:

10 October 2016

\section{A B S T R A C T}

Aspergillus terreus BAB-346 was isolated from various agro-industrial wastes dumping site of Anand region and screened for alkaline protease enzyme production. A comparative study was carried out on the production of Alkaline protease using different type of agro-industrial waste viz. Paper pulp waste, banana stem waste and poultry litter waste as substrate in submerged medium. Amongst the various isolates, A.terreus BAB-346 produced the highest enzyme activity at $120 \mathrm{~h}$ of incubation as $330.0 \mathrm{U} \mathrm{mg}^{-1}$ using Poultry litter as the sole carbon source. However, produced enzyme was partially purified as 2.5 fold by Ammonium sulphate fractionation. The purified enzyme has temperature and $\mathrm{pH}$ optimal of $60^{\circ} \mathrm{C}$ and 8.0, respectively. Purified alkaline protease is tharmostable in nature and retained fully active even at end of 20 minute of incubation at $60^{\circ} \mathrm{C}$. The Alkaline protease was completely inhibited by $\mathrm{Hg}^{+2}, \mathrm{Ca}^{+2}$, with little increase $(22 \%)$ in the activity of upon addition of $\mathrm{Mn}^{+2}$ metal ions. It is envisaged that the isolate can be a potential source of Akaline protease for use as additive in industrial application like detergent industry.

\section{Introduction}

The Poultry industry has seen phenomenal growth worldwide. This fast growth has inevitably resulted in various problems especially in the environmental side because rapid transformation in environmental management is not possible (Guru, 2003).In India, there are about 3430 million population of Poultry with waste generate of
3.30 million tons per year (Lakshman et al., 2005). The localization nature of poultry production also means that it can represent a large percentage of the agricultural economy in many states or regions. Although economical and successful, the Poultry industry is currently facing with a number of highly complex and challenging 
environmental problems, many of which are related to its size and geographically concentrated nature from an agricultural perspective, poultry wastes play a major role in the contamination of ground water through nitrate nitrogen. Also the surface eutrophication of surface water due to phosphorus, pesticides, heavy metals and pathogens present in the poultry wastes applied to solid are the central environmental issues at the present time. Among the animal manures, poultry droppings have higher nutrient content. There component upon microbial action can be converted to value added compost with high nutrient status. In poultry dropping nearly $60 \%$ of nitrogen which is present as uric acid and urea is lost through ammonia volatilization by hydrolysis (Mahimairaja et al., 2008). Different enzyme such as Amylase, Protease, Xylanase, Lipase, Phytase, Cellulose, Pectinase, Keratinase, Invertase, Carboxypeptidase, Hydrolase, $\beta-$ galactosidase \& Gelatinase, has been produced using such waste. Proteases constitute a group of enzymes that cleaves the peptide bonds of proteins and peptides. Proteases have a wide range of function in nature. Extracellular microbial proteinases contribute to the nutritional well being of producing organism by hydrolyzing large polypeptide substrata into smaller molecules that the cell can absorb, in mammalian pancreatic proteases and intestinal and stomach peptidases generally perform a similar nutritional role in the digestion and absorption processes of these species. Proteases are involved in the modulation of gene expression, and in enzyme modification and secretion. A variety of microorganisms such as bacteria, fungi, yeast and actinomycetes are known to produce proteases (Madan et al., 2002). Molds of genera Aspergillus, Penicillium and Rhizopus are especially useful for production of proteases, as several species of these genera are generally regarded as safe Microorganisms (Sandhya et al., 2005). By keeping the above points in mind present work presents the production of alkaline protease using poultry litter. Hence produced enzyme was partially purified and kinetic properties were characterized.

\section{Material and Methods}

\section{Isolation of fungi}

Proteolytic fungi were isolated from various soil samples, procured from three main regions: 1) Paper mill area, 2) Banana Farm, 3) Poultry Farm area. Each sample were collected in U.V. sterilized sample bag and stored at $4^{\circ} \mathrm{Cbefore}$ use. Appropriate dilutions from each sample were prepared and $0.1 \mathrm{~mL}$ of each diluted sample was spreader on to the following media to get different fungal isolates on the plate.

\section{Malt Extract agar}

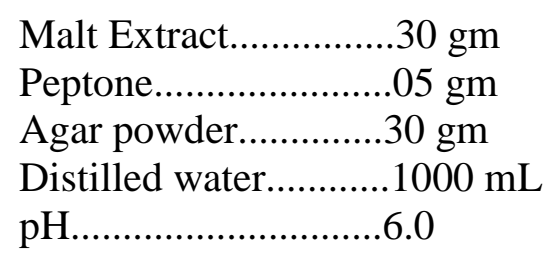

\section{Screening of proteolytic fungi}

Proteolytic fungi were directly screened out by observing the zone of hydrolysis surrounding colonies on Skim Milk Agar plate. All screened fungal isolates were picked up and pure culture of each isolates was prepared by repeated transferring it on to Malt Extract agar. After getting pure culture of each fungal isolates it was stored at $4^{\circ} \mathrm{C}$ and used further for identification.

Skim Milk Agar ( $p H-10)$

Skim milk powder........... $30 \mathrm{~g} / \mathrm{L}$

Nutrient agar.................. $1000 \mathrm{~mL}$

Distilled water................ $1000 \mathrm{~mL}$ 
Both the Skim Milk agar powder and Nutrient agar were separately sterilized in autoclave at $121^{\circ} \mathrm{C}$ for $20 \mathrm{~min}$ and aseptically mixed after it. After inoculation all the plates were incubated at $37^{\circ} \mathrm{C}$ for $24 \mathrm{hr}$.

\section{Identification of Alkaline protease producing fungi}

Potent alkaline protease producing fungal isolate was identified on the basis of colonial and morphological characteristic by growing them on to the Malt extract agar plate as well as the selected fungal isolate was identified using FAST Microseq ${ }^{\circledR}$ D2 LSU rDNA fungal identification kit. (Applied Biosystems, Foster city, CA, USA). DNA extraction was carried out using Prepman ${ }^{\mathrm{TM}}$ ultra sample preparation reagent and D2 LSU rRNA gene was amplified and cycle sequencing was carried out as per the kit instructions. Amplification was carried out in a thermal cycler (9800, Applied Biosystems, Foster city, CA, USA) with reaction profile: initial denaturation at $95^{\circ} \mathrm{C}$ for $10 \mathrm{~s}$ followed by 35 cycles of denaturation $95^{\circ} \mathrm{C}$ for $30 \mathrm{~s}$, annealing at $64^{\circ} \mathrm{C}$ for $15 \mathrm{~s}$, extension at $72^{\circ} \mathrm{C}$ for $1 \mathrm{~min}$ and finally extension at $72^{\circ} \mathrm{C}$ for $5 \mathrm{~min}$. The purified PCR product was sequenced and the phylogenic relationship of the isolate was determined by comparing the sequence data with the existing sequences available through the gene bank database of the National Center for Biotechnology Information (NCBI, Bethesda, MD, USA).

\section{Production media}

For the production of protease enzyme the waste residue cleaned, ground and sieved to get $2 \mathrm{~mm}$ particle size and each following $100 \mathrm{~mL}$ production medium set were prepared in $250 \mathrm{~mL}$ conical flasks.
I. Gelatin $(1 \%)+$ Vogel minimal salt media

II. Casein $(1 \%)+$ Vogel minimal salt media

III. Paper pulp waste $(1 \%)+$ Vogel minimal salt media

IV. Banana stem waste $(1 \%)+$ Vogel minimal salt media

V. Poultry litter waste $(1 \%)+$ Vogel minimal salt media

Vogel minimal salt media use for protease production.

$\begin{array}{lc}\text { Tri Sodium Citrate. } 2 \mathrm{H}_{2} \mathrm{O} & : 0.25 \mathrm{~g} \\ \mathrm{KH}_{2} \mathrm{PO}_{4} \text { Anhydhrous } & : 0.5 \mathrm{~g} \\ \mathrm{NH}_{4} \mathrm{NO}_{3} & : 0.2 \mathrm{~g} \\ \mathrm{MgSO}_{4} .7 \mathrm{H}_{2} \mathrm{O} & : 0.01 \mathrm{~g} \\ \mathrm{CaCl}_{2} .2 \mathrm{H}_{2} \mathrm{O} & : 0.01 \mathrm{~g} \\ \text { Trance Element Solution } & : 0.01 \mathrm{~mL} \\ \text { Biotin Solution } & : 0.005 \mathrm{~mL} \\ \text { Distilled Water } & : 100 \mathrm{~mL} \\ \text { Yeast extract } & : 0.25 \mathrm{~g} \\ \text { pH } & : 8.0\end{array}$

Trance element $(100 \mathrm{~mL})$

Citric acid $\quad: 5 \mathrm{~g}$

$\mathrm{ZnSO}_{4} 7 \mathrm{H}_{2} \mathrm{O} \quad: 5 \mathrm{~g}$

$\mathrm{Fe}\left(\mathrm{NH}_{4}\right)_{2}\left(\mathrm{SO}_{4}\right)_{2} .6 \mathrm{H}_{2} \mathrm{O} \quad: 1 \mathrm{~g}$

$\mathrm{CuSO}_{4} 5 \mathrm{H}_{2} \mathrm{O} \quad: 0.25 \mathrm{~g}$

$\mathrm{MnSO}_{4} . \mathrm{H}_{2} \mathrm{O} \quad: 0.05 \mathrm{~g}$

$\mathrm{H}_{3} \mathrm{BO}_{3} \quad: 0.05 \mathrm{~g}$

$\mathrm{Na}_{2} \mathrm{MoO}_{4} .2 \mathrm{H}_{2} \mathrm{O} \quad: 0.05 \mathrm{~g}$

For enzyme production, a $1 \times 10^{6}$ spores $/ \mathrm{mL}$ was inoculated into $250 \mathrm{~mL}$ conical flask containing $100 \mathrm{~mL}$ of the Vogel minimal medium (pH-8) with $1 \%$ of different waste as following and incubates $28{ }^{\circ} \mathrm{C}$ in an orbital shaker (140 rpm).

After 24, 48, 72, 96 and 120 hours time interval samples were withdraws, centrifuged to remove biomass and supernant were taken for different estimation. 


\section{Enzyme assay}

Protease activity was assayed by a modified method of Tsuchizla et al., (1986) by using casein as substrate.The enzyme reaction carried out using $100 \mu \mathrm{l}$ of enzyme solution was added to $900 \mu 1$ of substrate solution (2 $\mathrm{mg} / \mathrm{ml} \mathrm{(w/v)} \mathrm{casein} \mathrm{in} 10 \mathrm{Mm}$ Tris- $\mathrm{HCl}$ buffer( $\mathrm{pH} 8)$. The mixture was incubated at $45^{\circ} \mathrm{C}$ for $30 \mathrm{~min}$. Reaction was terminates by the addition of an equal volume of $10 \%$ $(w / v)$ chilled trichloroacetic acid then the reaction mixture was allowed to stand in ice for $15 \mathrm{~min}$ to precipitate the insoluble protein. The supernatant was separated by centrifugation at 10,000 rpm for $10 \mathrm{~min}$ at 4 ${ }^{\circ} \mathrm{C}$. The acid soluble product in the supernatant was neutralized with $5 \mathrm{ml}$ of 0.5 $\mathrm{m} \mathrm{Na} \mathrm{CO}_{3}$ solution. The color developed after adding $0.5 \mathrm{~mL}$ of 3 -fold-diluted folinciocalteau reagent was measured at $660 \mathrm{~nm}$.One unit of protease activity was defined as the unit of enzyme required to liberate $\mu \mathrm{g}$ of product equivalent to tyrosine per min per ml under the standard assay condition. The specific activity was expressed in unit per mg of protein.

\section{Protein determination}

Total soluble protein was estimated according to Bradford's method (Bradford, 1976) employing bovine serum albumin as a standard.

\section{Partially purification of alkaline protease enzyme}

All steps were done at $4^{\circ} \mathrm{C}$

Step 1: filtration. After $120 \mathrm{hrs}$ of production all the content of flask were centrifuged at $1000 \mathrm{rpm}$ for $10 \mathrm{~min}$ following by supernant was again passed though Whatman filter paper to remove biomass and unutilized media particles.
Step 2: Ammonium sulphate fractionation. To enzyme solution, solid ammonium sulphate was slowly added to $60 \%$ saturation. After the mixture was left for 30 min on stirrer, the precipitate was collected by centrifugation and dissolved in minimum volume $10 \mathrm{mM}$ Tris-HCL buffer $\mathrm{pH} 8$, and then dialyzed against the same buffer.

Effect of $\mathrm{pH}$ and temperature on the activity and stability of alkaline protease enzyme

To determine the effect of temperature on the alkaline protease enzyme activity, the standard enzyme assay was followed except with various incubation temperatures (30$\left.80^{\circ} \mathrm{C}\right)$. When the tests of thermal stability were performed, the enzyme was preincubated in $10 \mathrm{mMTris}-\mathrm{HCL}$ buffer $(\mathrm{pH}$ $8.0)$ at $60^{\circ} \mathrm{C}$ over a period of $5-60 \mathrm{~min}$. The residual enzyme activity was then determined under the standard condition. For the determination of $\mathrm{pH}$ effect on alkaline protease enzyme activity, the standard assay was used over a $\mathrm{pH}$ range of 6.0-12.0. The residual enzyme activity was then determined under the standard condition.

\section{Effect of various metal ions on alkaline protease enzyme activity}

The effect of various metal ions viz. $\mathrm{Ca}^{+2}$, $\mathrm{Mn}^{+2}, \mathrm{Zn}^{+2}, \mathrm{Hg}^{+2}, \mathrm{Cu}^{+2}$ and $\mathrm{Mg}^{+2}$ (Chloride and Sulphate salts @ 5mM)on enzyme activity were investigated by adding $1 \mathrm{ml}$ of each metal solutioninto the reaction mixture incubated for $20 \mathrm{~min}$ at $60^{\circ} \mathrm{C}(\mathrm{pH} 8)$. The activity of enzyme was measured.

\section{Effect of organic solvents on the alkaline protease stability}

Organic solvents used were methanol, ethyl acetate, benzene, glycerol, toluene, acetone 
and isopropanol. In the stability test $1.0 \mathrm{~mL}$ of organic solvent $(100 \% \mathrm{v} / \mathrm{v})$ was added to $1 \mathrm{~mL}$ of the reaction mixture and preincubated at $60{ }^{\mathrm{O}} \mathrm{C}$ for $20 \mathrm{~min}(\mathrm{pH} 8)$. The remaining proteolytic activity was measured.

\section{Determination of kinetic parameters}

The kinetic parameters, Michaelis constants $\left(K_{\mathrm{m}}\right)$ and maximal velocities $\left(V_{\max }\right)$, of Akaline protease were determined in reference to the Casein substrate. A linear regression was used to analyze and obtain Lineweaver-Burk plots and $K_{\mathrm{m}}$ and $V_{\max }$ also were calculated. This investigation was carried out by the concentration range of 0.2 to $2 \mathrm{mg}$ at the optimal $\mathrm{pH} 8$ and temperature $\left(60^{\circ} \mathrm{C}\right)$.

\section{Results and Discussion}

Isolation, screening and identification of the fungal isolate

For the isolation of proteolytic fungi different soil samples were collected from the Banana farm, Paper mill area and poultry farm surrounding Anand region. Pure cultures of each isolates were selected for screening purpose. Screenings of proteolytic fungi were easily carried out by growing the isolates on $1 \%$ Skim Milk agar plate $(\mathrm{pH}$ 10) and observing the zone of hydrolysis of casein protein surrounding colony (Fig.1).

Best alkaline proteolytic producer shows 6 $\mathrm{mm}$ zone of hydrolysis whereas, other fungal isolate shows zone of hydrolysis in the range of 1 to $5 \mathrm{~mm}$ which were further used for production of enzyme. Potent fungal isolate was further identified at molecular level. The sequence had $97 \%$ homology with $A$. terreus showing 435 maximum score having $3 \mathrm{e}-118 \mathrm{e}$-value. The sequence was deposited in the NCBI gene bank bearing the Accession no. JN662343.
The evolutionary history was inferred using the Neighbor-Joining method (Saitou and Nei, 1987). The optimal tree with the sum of branch length $=1.077$ is shown. The percentage of replicate trees in which the associated taxa clustered together in the bootstrap test (1000 replicates) is shown next to the branches (Felsenstein, 1985). The evolutionary distances were computed using the Maximum Composite Likelihood method and are in the units of the number of base substitutions per site. The analysis involved 12 nucleotide sequences. All positions containing gaps and missing data were eliminated. There were a total of 218 positions in the final dataset. The phylogenic tree was drawn using bioinformatics software MEGA 5.05 (Fig.2).

Production of alkaline protease from various agro-industrial wastes using $\mathrm{A}$. terreus BAB-346

Various reports has been published for the production of alkaline protease production using crude agro-industrial wastes as a carbon and nitrogen source such as Rice mill waste for Aspergillus niger, Poultry waste for Pseudomonas thermaerumGW1, Soybean for Bacillus sp., Molasses, Wheat flour and Wheat bran for Alkaliphilic actinomycete and Rice bran for Aspergillus oryzae, (Paranthaman et al., 2009; Gaur et al., 2010; Saurabh et al., 2007; Mehta et al., 2006; Chutmanop et al., 2008). In present work also we selected various cheap and easily available waste materials such as banana stem waste, paper pulp waste and poultry litter waste for the production of alkaline protease enzyme. Production of alkaline protease enzyme varies from organisms to organisms and using different substrate such as rice bran by $A$. oryzae and A. niger, wheat bran Bacillus sp. and actinomycete (Paranthaman et al., 2009; Mona et al., 2006; Mehta et al., 2006). 
Poultry litter is the good source for the production of enzyme compared to other substrate and shows the production in the range of 0.76 to $330.0 \mathrm{IU} \mathrm{mg} \mathrm{mg}^{-1}$ (Table 1) However, amongst all the isolated fungi, A.terreus BAB-346 shows maximum enzyme production using poultry litter that is $330 \mathrm{IU} \mathrm{mg}^{-1}$ at $120 \mathrm{~h}$ of incubation. Due to higher amount of total protein and nitrogen content in poultry litter compared to other substrate provides precursors for the synthesis of protease enzyme. Our results are also in tune with Paranthaman et al., 2009.

\section{Partial purification of alkaline protease enzyme}

After the selection of potential substrate and isolate for the production of enzyme, produced enzyme was purified on the basis of protein solubility using ammonium sulphate fractionation.

The main draw back with production of bacterial protease is the requirement of cost intensive procedure for separation of enzymes from cells. On the other hand enzyme from fungal origin offers an advantage of extracellular enzyme which is easily separated from mycelium by simple filtration. At 60-65 \% saturation concentration of ammonium sulphate significant level of protein was pooled and was dialyzed against 10mM Tris-HCL buffer (pH-8). Purification of alkaline protease resulted in 2.5 fold and purification with $85 \%$ recovery (Table 2). Similar observation was also reported by Gaur et al., (2010). Purified enzyme solution was stored at $4^{\circ} \mathrm{C}$ and further used to study the kinetics of it.

\section{Alkaline protease enzyme characterization}

Temperature optimization and Thermal stability

Temperature is a critical factor for maximum enzyme activity and it is a prerequisite for industrial enzyme to be active and stable at higher temperature. Assay mixture was incubated at different temperature ranging from 10 to $80^{\circ} \mathrm{C}$ and maximum enzyme activity was found at $60^{\circ} \mathrm{C}$ (Figure 3). Lowering or rising the temperature from $60^{\circ} \mathrm{C}$ resulted in reduction of alkaline protease activity. Alkaline protease of $A$. terreus BAB-346 was most active at $60^{\circ} \mathrm{C}$ resembling alkaline protease of A. usami (Morimarvet al., 1994).

Table.1 Effect of various agro-industrial wastes on production of alkaline protease enzyme using A.terreus BAB-346.

\begin{tabular}{cccccc}
\hline Time & \multicolumn{5}{c}{ Specific activity IU mg } \\
Interval (h) & Paper pulp & $\begin{array}{c}\text { Banana } \\
\text { stem }\end{array}$ & $\begin{array}{c}\text { Poultry } \\
\text { litter }\end{array}$ & Casein & Gelatin \\
\hline 24 & 0.76 & 30.1 & 37.5 & 1.43 & 0.76 \\
48 & 8.32 & 35.4 & 55.3 & 1.72 & 1.34 \\
72 & 12.0 & 38.0 & 59.0 & 16.18 & 1.52 \\
96 & 33.2 & 40.6 & 60.6 & 7.55 & 3.29 \\
120 & 141.6 & 11.1 & 330.0 & 3.35 & 20.1 \\
144 & 1.2 & 2.32 & 12.7 & 0.82 & 10.8 \\
\hline
\end{tabular}


Table.2 Partial purification of alkaline protease enzyme

\begin{tabular}{lccccc}
\hline Fractionation Steps & $\begin{array}{l}\text { Unit } \\
\text { Activity } \\
\text { (IU/ml) }\end{array}$ & $\begin{array}{l}\text { Protein } \\
\text { (mg/ml) }\end{array}$ & $\begin{array}{l}\text { Specific } \\
\text { activity } \\
\text { (IU/mg) }\end{array}$ & $\begin{array}{l}\text { Purification } \\
\text { (fold) }\end{array}$ & $\begin{array}{l}\text { Recovery } \\
\text { Yield(\%) }\end{array}$ \\
\hline $\begin{array}{l}\text { Culture filtration } \\
\begin{array}{l}\text { Ammonium sulphate } \\
\text { fractionation }\end{array}\end{array}$ & 20 & 0.060 & 333.3 & 1 & 100 \\
\hline
\end{tabular}

Fig.1 Zone of hydrolysis of casein protein surrounding screened fungus colony

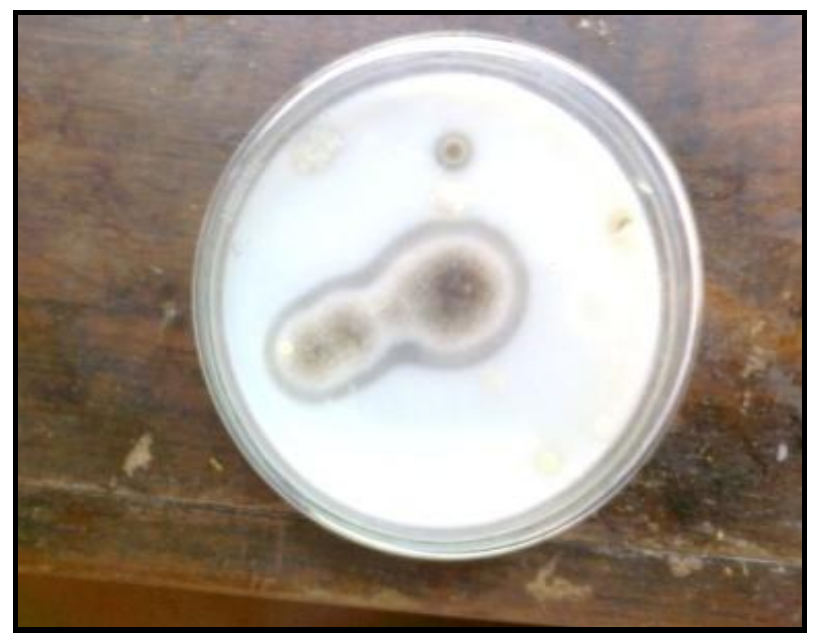

Fig.2 Phylogenetic relationships on the basis of homology index for a proteolytic fungal isolate A. terreus BAB-346

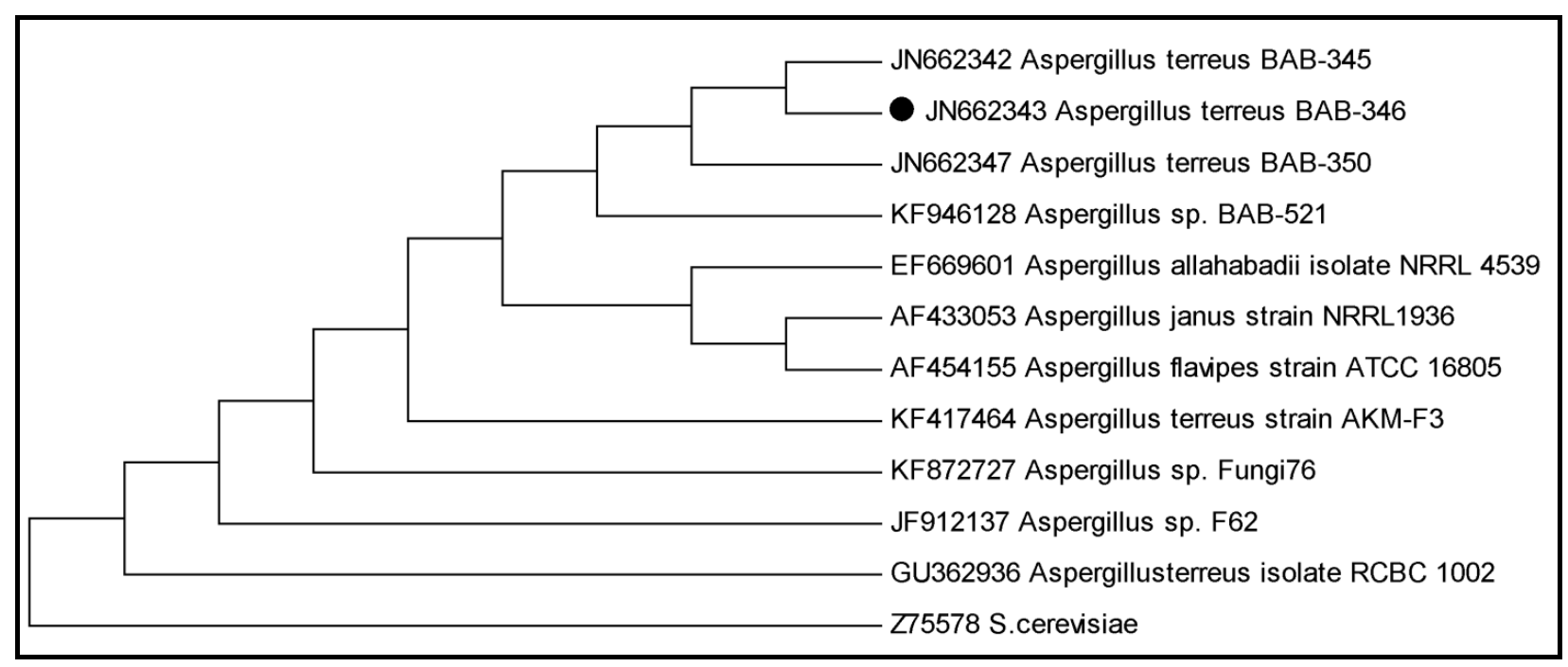


Fig.3 Effect of Temperature on the relative activity of alkaline protease enzyme

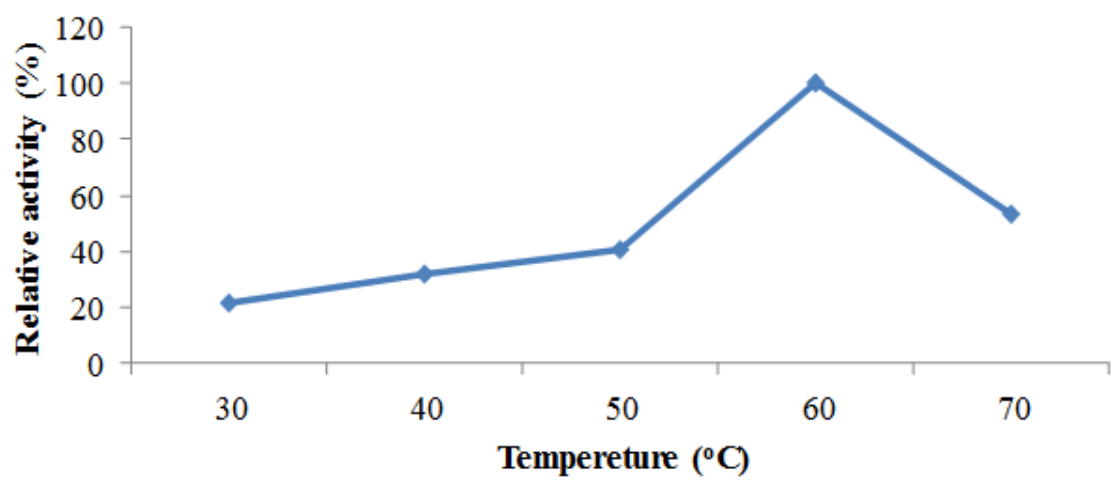

Fig.4 Thermo stability of alkaline protease at $60^{\circ} \mathrm{C}$

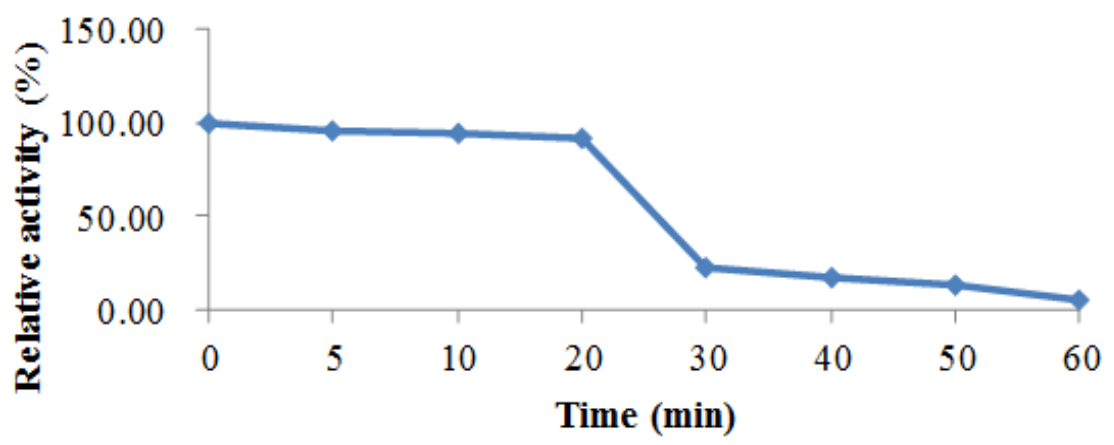

Fig.5 Effect of $\mathrm{pH}$ on the relative activity of alkaline protease enzyme

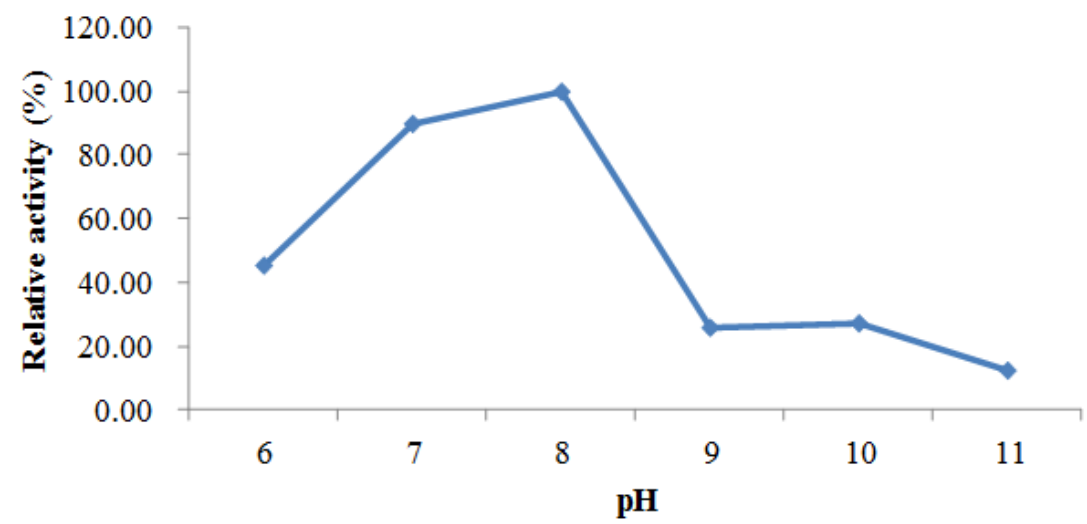


Fig.6 Effect of Metal ions on alkaline protease enzyme activity
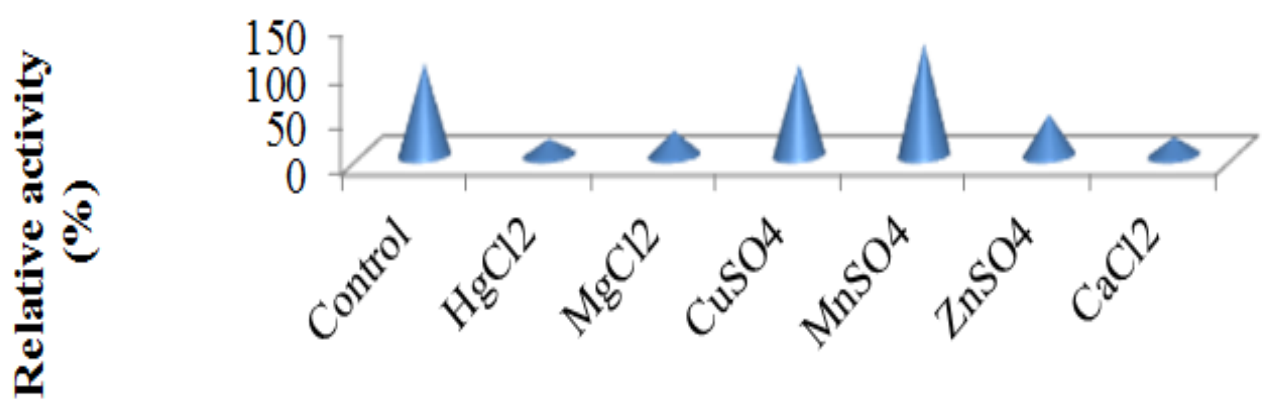

\section{Metal ions}

Fig.7 Effect of various organic solvents on alkaline protease enzyme activity

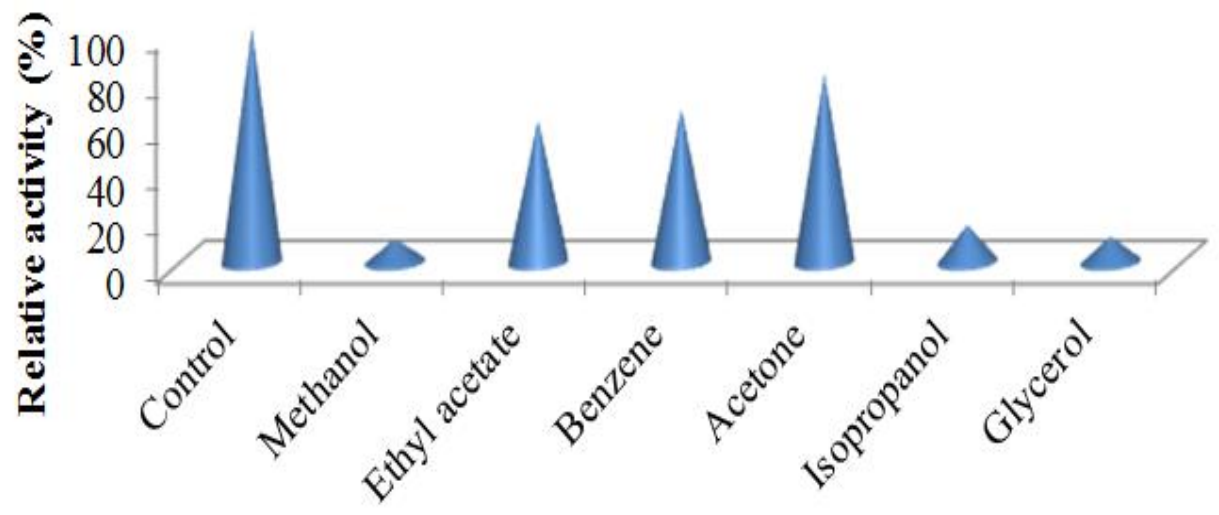

Organic solvent

Fig.8 Lineweaver-Burk Plot showing the parameter Km and Vmax of alkaline protease

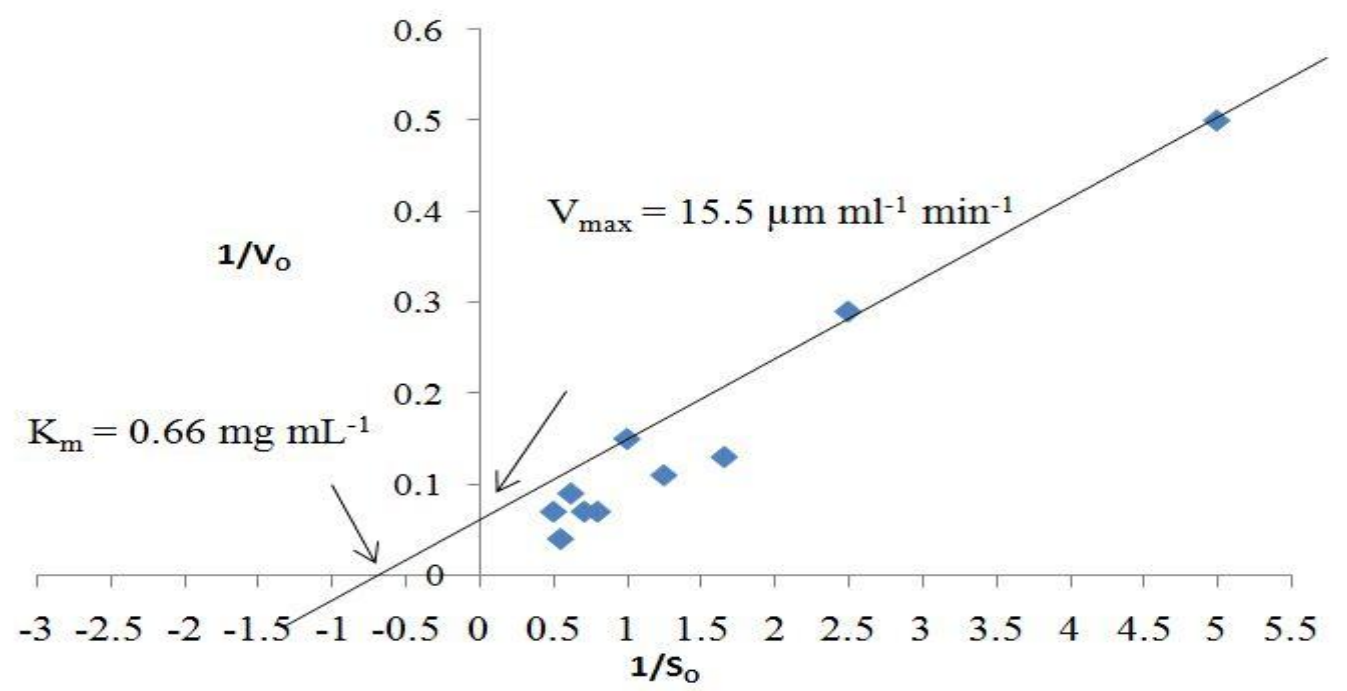

For test of the thermal stability, enzyme solution was kept at $60^{\circ} \mathrm{C}$ for 5 to $60 \mathrm{~min}$. and the remaining enzyme activity was determined. It was found that alkaline protease of A.terreus BAB-346 stable at $60^{\circ} \mathrm{C}$ (Fig.4). The half life $\left(\mathrm{T}_{1 / 2}\right)$ at $60^{\circ} \mathrm{C}$ was 
$20 \mathrm{~min}$. On the other hand, the activity of the enzyme diminished rapidly after holding above 20 minute.

\section{pH optimization}

To determine the effect of $\mathrm{pH}$ on the enzyme activity, the enzyme activity was measured over a pH range of 6 to 11 (Fig. 5). The partially purified alkaline protease of A.terreusBAB-346 showed the maximum activity $916.0 \mathrm{IUmg}^{-1}$ at $\mathrm{pH} 8.0$ coming close to those of Bacillus thuringiensis $\mathrm{pH}$ 8.0 (Chudasama et al., 2010), Pseudomonas thermaerum $\mathrm{pH} 8.0$ (Gaur et al., 2010) and Bacillus subtilis pH 8.0 (Gitishree et al., 2010) but in contrast optimal $\mathrm{pH} 10.0$ and 10.5 for the Alkaline protease from Aspergillus niger (Kalpana Devi et al., 2008) and Vibrio metschikovii (Durham et al., 1987) respectively.

\section{Effect of metal ions on the activity of} alkaline protease enzyme

Effect of various metal ions $(5 \mathrm{mM}$ of chloride and sulphate salts) on the activity of alkaline protease from A. terreus BAB-346 is shown in (Fig.6).Of all the tested ions $\mathrm{Hg}^{+2}, \mathrm{Zn}^{+2}, \mathrm{Mg}^{+2}$ and $\mathrm{Ca}^{+2}$ inhibit the activity up to $82 \%, 80 \%, 73 \%$ and $55 \%$, respectively. The present study results are also in tune with Guar et al., 2010 for $\mathrm{Mg}^{+2}$ and $\mathrm{Zn}^{+2}$ Metal ion using Pseudomonas $s p$. and Chudasama et al., 2010 for $\mathrm{Mg}^{+2}$ and $\mathrm{Ca}^{+2}$ using Bacillus sp. Interestingly, $\mathrm{Mn}^{+2}$ and $\mathrm{Cu}^{+2}$ increased or stabilized the activity of the enzyme up to $122 \%$ and $100 \%$ respectively. Results confirming that may these cations take part in the stabilization of the protease structure and are required for protection against thermal denaturation (Paliwal et al., 1994).

\section{Effect of organic solvents on alkaline protease stability}

Six organic solvent were used to study the effect on alkaline protease activity using $A$. terreus BAB-346. As shown in figure 7 enzyme has ability to act in the present of solvent in reaction system. The enzyme retained $81 \%, 66 \%, 61 \%$ of activity in the presence of Acetone, Benzene and Isopropanol respectively whereas; enzyme lost its activity up to $90 \%, 89 \%$ and $84 \%$ of total activity in the presence of Methanol, Glycerol and Ethyl acetate respectively. Various investigators reported that the activity protease was affected by Glycerol (Gaur et al., 2010).

\section{Determination of kinetic parameters}

Initial reaction rate was determined as the amount of casein hydrolysis ( $2 \mathrm{mg}$ ) per min against various substrate concentrations $(\mathrm{pH}$ 8 and Temperature $60^{\circ} \mathrm{C}$ ). The $\mathrm{K}_{\mathrm{m}}$ value and maximal velocity for the reaction with casein was calculated form a LineweaverBurk plot. The $\mathrm{K}_{\mathrm{m}}$ value was $0.66 \mathrm{mg} \mathrm{ml}^{-1}$ which was comparable with the alkaline protease of Aspergillus nigeras reported by Kalpanadevi et al., 2008. This work proved that alkaline protease could be produced from the agro-industrial wastes and hence poultry litter is the potent substrate for production of this enzyme.

\section{References}

Bradford, M.M. 1979. A rapid and sensitive method for the quantization of microgram quantities of protein utilizing the principle of protein-dye binding, Anal. Biochem., 72: 248-254.

Chudasama, C.J., Jani, S.A., Jajda, H.M. and Patel, H.N. 2010. Optimization and Production of Alkaline protease from Bacillus thuringiensis. J. Cell and Tissue Res., 10(2): 2257-2262.

Chutmanop, J., Chuichlcherm, S., Chisti, Y. and Srinophokum, P. 2008. Protease production by Aspergillus oryzae in solid state fermentation using Agro industrial substrate, Chem. Technol. Biotechnol., 
83: 1012-1018.

Durham, D.R. 1987. Utility of subtilisin GX as a detergent additive. J Appl Biotechol., 63: 381-386.

Felsenstein, J. 1985. Confidence limits on phylogenies: An approach using the bootstrap. Evol., 39: 783-791.

Gaur, S., Agradhari, S. and Neeraj, W, 2010. Purification of protease From Pseudomonas thermaerum GW1 isolated from poultry waste site. The Pen Micr. J., 4: 67-74.

Gitishree, D. and M.P. Prasad. 2010. Isolation, purification and mass production of Protease enzyme from Bacillus subtilis. J. Microbiol., Vol. 1(2): 026-031.

Guru, M. 2003. Effect of poultry litter management and land application on contract Poultry growers. Public policy working paper series, Vol. 2 no. 5.

Kalpana Devi, M., Rasheedha Banu, A., Gnunaprabhal, G.R., Pradeep, B.V. and Pallaniswamy, M. 2008. Purification and characterization of Alkaline protease Enzyme from native isolated Aspergillus niger and its compatibility with Commercial detergent. Indian. J. Sci. Tech., Vol. 1 No 7.

Madan, M., Dhillon, S. and Singh, R. 2002. Production of Alkaline protease by a U.V Mutant of Bacillus polymyxa. Ind. J. Microbiol., 42: 155-159.

Mahimaraja, S., P. Dooraisamy, A. Lakshmanan, G. Rajannan, C. Udayasooriaand, S. Natarajan. 2008. Composting technology and organic waste utilization in agriculture A.E. Publication, P.N. Pundur, conbatore: 641-041.

Mehta, V.J., Thumar, J.T., Singh, S.P. 2006. Production of alkaline protease from alkaliphilic actinomycetes. Bioresour.
Technol., 97: 1650-1654.

Mona, K., Otouda. 2006. Optimization and purification of Alkaline protease produce by marine Bacillus sp. MIG newly isolated from Harbour of Alexandria, $J$. Microbiol., Vol. 55: No-2: 119-126.

Morikawa, M., Izawa, Y., Rashid, N., Hoaki, T., Imanaka, T. 1994. Purification and characterization of a thermostablethiol protease from a newly isolated hyperthermophilic Pyrococcus sp. Appl. Environ Microbiol., 60(12): 4559-66.

Paliwal, N., S.P. Singh and S.K. Garg. 1994. Cation induce thermal stability of an Alkaline protease from Bacillus $s p$. Biores. Technol., 50: 209-211.

Paranthaman, R., Alagusundaram, K. and Indhumathi, J. 2009. Production of Protease from Rice Mill Wastes by Aspergillus niger in Solid State Fermentation. J. Agri. Sci., 5(3): 308312.

Saitou, N. and Nei, M. 1987. The neighborjoining method: A new method for reconstructing phylogenetic trees. Mol. Biol. Evol., 4: 406-425.

Sandhya, C., Sumantha, A., Szakacs, G. and Pandey, A. 2005. Comparative evaluation of neutral protease production by Aspergillus oryzae in submerged and solid state fermentation. Process Biochem 40: 2689- 2694.

Saurabh, S., J. Asmine, L., Peitesh, G. And Rajendrakumar, S. 2007. Enhance Productivity of serine Alkaline protease by Bacillus sp. Using soyabean as Substrata. J. Microbiol., Vol. 3(1): 1-6.

Tsuchizla, O., Yamagota, Y., Ishizuka, J., et al. 1986. An Alkaline proteinase of an Alkalophilic Bacillus sp. Curr. Microbial., 14: 7-12.

\section{How to cite this article:}

Gopalkumar G. Raol, Priyanka M. Patel, B.V. Raol and Rakeshkumar R. Panchal. 2016. Alkaline Protease Production by Aspergillus terreus BAB-346 using Poultry Litter Waste. Int.J.Curr.Microbiol.App.Sci. 5(10): 174-184. doi: http://dx.doi.org/10.20546/ijcmas.2016.510.020 